\title{
Fertilizer Micro-dosing and Timing of Weeding for Enhancing Finger-Millet Production in Eastern Uganda
}

\author{
J. Ekwangu ${ }^{1}$, P. Anguria ${ }^{1}$, C. Andiku ${ }^{1}$, J. S. Tenywa ${ }^{2}$, J. Bisikwa ${ }^{2}$, N. Wanyera ${ }^{1} \&$ M. A. Ugen ${ }^{1}$ \\ ${ }^{1}$ National Semi Arid Resources Research Institute (NaSARRI), Soroti, Uganda \\ ${ }^{2}$ Department of Crop Production, Makerere University, Kampala, Uganda \\ Correspondence: J. Ekwangu, National Semi Arid Resources Research Institute (NaSARRI), Serere, P.O. Box 56, \\ Soroti, Uganda. E-mail: jekwangu@gmail.com
}

\author{
Received: April 18, $2019 \quad$ Accepted: September 2, $2020 \quad$ Online Published: October 15, 2020 \\ doi:10.5539/jas.v12n11p290 URL: https://doi.org/10.5539/jas.v12n11p290
}

This research is financed by Harnessing Opportunities for Productivity Enhancement of Sorghum and Millets II (HOPE II) and $M^{c}$ KNIGHT Foundation.

\begin{abstract}
Finger-millet response to micro-dosing with $\mathrm{N}$ and $\mathrm{P}$ fertilizer in the Semi-Arid areas of eastern Uganda is not fully known. Consequently, we conducted a field study at Kuju in eastern Uganda in 2016 long and short rains. The study determined the effect of fertilizer micro-dosing and weeding time on finger-millet performance. The experiment was laid out in a randomized complete block design with a split plot treatment structure. Weeding time constituted the main plot (weeding at 20,30,45 DAS (days after sowing) and 20 + 45 DAS while fertilizer rates $\left(16.6 \mathrm{~kg} \mathrm{Nha}^{-1}+10.6 \mathrm{~kg} \mathrm{P}_{2} \mathrm{O}_{5} \mathrm{ha}^{-1} ; 10.6 \mathrm{~kg} \mathrm{P}_{2} \mathrm{O}_{5} \mathrm{ha}^{-1} ; 16.6 \mathrm{~kg} \mathrm{Nha}^{-1} ; 0 \mathrm{~N}+0 \mathrm{~N}\right.$ and $\left.83 \mathrm{~kg} \mathrm{~N} \mathrm{ha}^{-1}+52 \mathrm{~kg} \mathrm{P}_{2} \mathrm{O}_{5} \mathrm{ha}^{-1}\right)$ constituted the sub-plots. Results of this study revealed that finger-millet grain yield was highest $\left(2182 \mathrm{~kg} \mathrm{ha}^{-1}\right)$ at fertilizer micro-dosing $\left(16.6 \mathrm{~kg} \mathrm{~N} \mathrm{ha}^{-1}+10.6 \mathrm{~kg} \mathrm{P}_{2} \mathrm{O}_{5} \mathrm{ha}^{-1}\right)$ and lowest $\left(950 \mathrm{~kg} \mathrm{ha}^{-1}\right)$ in plots with no fertilizer. Fertilizer micro-dose application ( $\left.16.6 \mathrm{~kg} \mathrm{~N} \mathrm{ha}^{-1}+10.6 \mathrm{~kg} \mathrm{P}_{2} \mathrm{O}_{5} \mathrm{ha}^{-1}\right)$ caused early flowering of finger-millet (52.2 days), whereas delayed flowering was recorded, where $16.6 \mathrm{~kg} \mathrm{~N}^{-1}$ (55.12 days) was applied. The interaction between time of weeding and fertilizer rates significantly $(\mathrm{P}<0.05)$ increased finger millet growth and grain yield. The interaction of $\mathrm{N}$ and $\mathrm{P}$ fertilizer micro-dose with weeding once at $20 \mathrm{DAS}$ had the highest finger-millet grain yield. Therefore, it is recommended that fertilizer micro-dosing can be used to enhance finger-millet productivity.
\end{abstract}

Keywords: full dose, fertilizer micro-dosing, days after sowing, timing of weeding

\section{Introduction}

Finger-millet (Eleusine coracana (L.) is a major food crop of the semi-arid tropics of Asia and Africa and fits well in dry land farming systems (Goron \& Raizada, 2015). The crop was domesticated in the highlands of Ethiopia and Uganda approximately 5000 years ago, and today it is ranked fourth globally in importance, after sorghum, pearl millet, and foxtail millet (Das, 2013). It is cultivated in more than 25 countries, mainly in Africa and Asia (Chandrasekara \& Shahidi, 2010).

In Uganda, finger-millet is rated second to maize (Zea mays L.) in importance among the cereals (Owere, Tongoona, Derera, \& Wanyera, 2014). The crop is grown on an estimated area of 175,173 ha annually which provides grain harvests of up to 236,484 metric tonnes (UBOS, 2016). Production of the crop is largely in the northern, eastern and western regions of the country (UBOS, 2016). It is grown mainly as a staple food crop, but also contributes greatly to the incomes of rural households, particularly women. Finger-millet has a number of uses that include; it is brewed into local beer for sale, ground into flour for porridge and bread, and also sold directly as grain in local markets where there is ready demand (Ebanyat, 2009; Owere, 2013). In addition, finger-millet plays a major role in providing for the dietary needs and incomes of the rural people who constitute more than $80 \%$ of the Ugandan population.

However, finger-millet productivity (yield per unit area) is declining from 2,500-2,600 $\mathrm{kg} \mathrm{ha}^{-1}$ (Kidoido, Kasenge, Mbowa, Tenywa, \& Nyende, 2002; Owere, 2013; Wanyera, 2007). This has been attributed to; low soil fertility and weed proliferation, moisture stress, pests and diseases and poor agronomic practices (Ebanyat, 2009; Opole, Prasad, \& Staggenborg, 2013). Nitrogen and phosphorous are the major limiting nutrients (Ebanyat, 2009; Owere, 
2013). It is possible to enhance finger-millet productivity by use of fertilizer, but most smallholder farmers are unable to use fertilizers due to high cost involved in their acquisition (ICRISAT, 2013). Consequently, there is need to develop and demonstrate more affordable technologies that small holder farmers can use to enhance soil fertility for finger-millet production. It would be more appropriate to develop technologies that minimize wastage and loss of fertilizer to ensure efficient utilization by the crop. This could be achieved through micro-dosing which is a localized placement of small amounts of fertilizer normally a third of the total crop requirement around the root zone of the plant (3-5cm away from stem base), (micro-dosing). Finger-millet response to micro-dosing with $\mathrm{N}$ and $\mathrm{P}$ fertilizer in the Semi-Arid areas of eastern Uganda is not fully known. This study determined the effect of fertilizer micro-dosing and timing of single weeding on finger-millet performance in Eastern Uganda.

\section{Materials and Methods}

\subsection{Study Site}

\subsubsection{Weather and Altitude}

This study was conducted in Kuju, sub-county in Amuria district Eastern Uganda. It is located at $02^{\circ} 02^{\prime} \mathrm{N} ; 33^{\circ} 39^{\prime} \mathrm{E}$ and $1140 \mathrm{~m}$ above sea level and covers an area of flat to gentle slope (UBOS, 2010). This area experiences mean annual rainfall of $1200 \mathrm{~mm}$ and is distributed in a bimodal pattern. The months of March to June and August to October or November receive substantial amount of precipitation, while months of December, January and February are drier with very little precipitation. The area experiences mean annual minimum and maximum temperature of $15{ }^{\circ} \mathrm{C}$ to $36^{\circ} \mathrm{C}$, respectively.

\subsubsection{Soil Properties}

The soils at the experimental site are predominantly free draining sandy loam which are susceptible to loss of plant nutrients especially $\mathrm{N}$ and $\mathrm{P}$. Laboratory analysis of the soils at the experimental sites revealed that $\mathrm{N}$ $(0.25 \%)$ and $\mathrm{P}\left(15 \mathrm{mg} \mathrm{kg}^{-1}\right)$ were below the critical level and the $\mathrm{pH}$ ranged from 5.1 to 5.2.

\subsection{Treatments, Experimental Design and Crop Husbandry}

The treatments comprised of; weeding by hand hoeing at 20 days after sowing (DAS), 30 DAS and 45 DAS and weeding twice at 20 and 45 DAS as main plot treatments, while $16.6 \mathrm{~kg} \mathrm{~N} \mathrm{ha}^{-1}+10.6 \mathrm{~kg} \mathrm{P}_{2} \mathrm{O}_{5}$ ha $^{-1} ; 10.6 \mathrm{~kg} \mathrm{P}_{2} \mathrm{O}_{5}$ $\mathrm{ha}^{-1} ; 16.6 \mathrm{~kg} \mathrm{~N} \mathrm{ha}^{-1} ; \mathrm{N} 0+\mathrm{P} 0$ and $83 \mathrm{~kg} \mathrm{~N} \mathrm{ha}^{-1}+53 \mathrm{~kg} \mathrm{P}_{2} \mathrm{O}_{5} \mathrm{ha}^{-1}$ as the sub plot treatments. The design was laid out in a randomized complete block design (RCBD) with a split plot arrangement. Land was prepared by ploughing with an ox-plough twice before planting. Finger-millet was planted by dibbling into the furrows created by sticks and later covered with soil. At 20 days after sowing, finger-millet was thinned to a spacing of $0.3 \mathrm{~m}$ by $0.1 \mathrm{~m}$ between rows and plants, respectively. Each plot measured 3 by $3 \mathrm{~m}$. Seremi II finger-millet variety was used, while Triple Super Phosphate (TSP) and Urea were used as the inorganic source of P and N, respectively and treatment replicated three times. Triple Super Phosphate (TSP) was applied in the planting hole at planting and urea was incorporated in the soil in between the finger-millet lines as a side dress.

\subsection{Data Collection}

Data was recorded on stand count, average tiller number per plot, scores of growth vigor (Hatier et al., 2014). Plant height $(\mathrm{cm})$, days to $50 \%$ flowering, maturity period (days) and grain yield $\left(\mathrm{kg} \mathrm{ha}^{-1}\right)$.

\subsection{Data Analysis}

Recorded data were subjected to analysis of variance (ANOVA) using Genstat statistical package $14^{\text {th }}$ edition. The means were compared using the least significant difference (LSD) test at $p \leq 0.05$. Correlation analysis was performed to determine the relationship between fertilizers micro-dosing and weed biomass, weed diversity and weed population $\left(\mathrm{M}^{-2}\right)$.

\section{Results}

\subsection{Effect of Weeding Time on Finger-Millet Growth Parameters and Yield}

The effect of time of weeding on finger-millet growth and grain yield was significant $(\mathrm{P}<0.05)$. Specifically, weeding once at 20 DAS gave the highest average growth vigor score of 3.77 followed by double weeding at 20 and 45 DAS (3.63). On the otherhand, weeding once at 20 DAS had the lowest number of days (93.20) to maturity and the highest average plant height attained $(94.00 \mathrm{~cm}$ ) followed by double weeding (at 20 and 45 DAS), Table 1. 
Table 1. Effect of timing of weeding on observed finger-millet growth parameters and yield

\begin{tabular}{|c|c|c|c|c|}
\hline Timing of weeding & Growth vigor score & Plant height (cm) & Maturity time (days) & Yield $\left(\mathrm{kg} \mathrm{ha}^{-1}\right)$ \\
\hline $20 \& 45$ DAS & 3.63 & 91.59 & 95.40 & 1626 \\
\hline $20 \mathrm{DAS}$ & 3.77 & 94.00 & 93.20 & 1716 \\
\hline $30 \mathrm{DAS}$ & 3.30 & 88.11 & 94.43 & 1652 \\
\hline 45 DAS & 2.70 & 89.81 & 94.90 & 1659 \\
\hline LSD & $0.4597^{\text {*** }}$ & $3.781^{\text {*a }}$ & $1.394^{* * *}$ & $376.1^{\mathrm{NS}}$ \\
\hline $\mathrm{CV}$ & 26.8 & 8.1 & 2.9 & 44.2 \\
\hline
\end{tabular}

Note. ${ }^{* * *}=$ significant at $0.001 ; *=$ significant at $0.05 ; \mathrm{NS}=$ not significant; $\mathrm{DAS}=$ days after sowing.

\subsection{Effect of Fertilizer Rates on Finger-Millet Growth Parameters and Yield.}

Finger-millet response to different rates of fertilizer was significant $(\mathrm{P}<0.05)$, particularity finger-millet grain yield response to fertilizer micro-dosing $\left(\mathrm{P}_{16.6} \mathrm{~kg} \mathrm{ha}^{-1}\right.$ and $\left.\mathrm{P}_{10.6} \mathrm{~kg} \mathrm{ha}^{-1}\right)$ was significant $(\mathrm{P}<0.001)$ with fertilizer micro-dosing having the highest average grain yield response of $2182 \mathrm{~kg} \mathrm{ha}^{-1}$ followed by full dose $\left(\mathrm{N}_{83} \mathrm{~kg} \mathrm{ha}^{-1}\right.$ and $\mathrm{P}_{52} \mathrm{~kg} \mathrm{ha}^{-1}$ ) with average yield of $2152 \mathrm{~kg} \mathrm{ha}^{-1}$ and the lowest grain yield recorded with no fertilizer applied. Similarly, fertilizer micro dosing caused early flowering of finger-millet followed by full dose, and delayed flowering was recorded with application of $\mathrm{P}_{10.6}$ (55.12) and no fertilizer also recorded the average days of 55.12 for attainment of $50 \%$ flowering. The lowest average maturity dates were observed in fertilizer micro-dosing (93.33) treatment followed by recommended dose (93.79). The same trend was observed with number of tillers (Table 2).

Table 2. Effect of fertilizer rates on growth parameters and yield

\begin{tabular}{llllll}
\hline Treatment & $\mathbf{5 0 \%}$ Flowering & Growth Vigor (score) & Maturity Time (days) & No. of Tillers & Yield (kg ha $^{-1}$ ) \\
\hline $\mathrm{N}_{16.6} \mathrm{P}_{10.6}$ & 53.46 & 3.625 & 93.33 & 2.48 & 2182 \\
$\mathrm{~N}_{16.6}$ & 54.21 & 2.917 & 94.12 & 2.51 & 1368 \\
$\mathrm{P}_{10.6}$ & 55.12 & 3.083 & 95.71 & 2.28 & 1665 \\
$\mathrm{~N}_{0} \mathrm{P}_{0}$ & 55.12 & 2.875 & 95.46 & 2.23 & 951 \\
$\mathrm{~N}_{83} \mathrm{P}_{53}$ & 53.54 & 4.250 & 93.79 & 3.00 & 2152 \\
$\mathrm{LSD}$ & 1.093 & 0.244 & 1.34 & 0.46 & 219.9 \\
$\mathrm{CV}$ & 4.2 & 25.0 & 2.9 & 43.1 & 39.9 \\
\hline
\end{tabular}

Note. $* * *=$ significant at $\mathrm{P}=0.001 ; * *=$ significant at $\mathrm{P}=0.01 ; *=$ significant at $\mathrm{P}=0.05$.

\subsection{Effect of Interaction Between Fertilizer Rates, Their Combinations $\times$ Timing of Weeding on Growth Parameters and Grain Yield}

\subsubsection{Tiller Number}

The effect of interaction of fertilizer micro-dosing of $\mathrm{N}$ and $\mathrm{P}$ with time of weeding on tiller number was only significant $(\mathrm{P}<0.05)$ when weeding was done at 20 DAS (Days after Sowing) (Table 2). Weeding at 20 and 45, 30 and 45 DAS had a negative interaction with fertilizer micro-dose application and consequently low tillering was observed when micro-dosing was done. 
Table 3. Interaction effect between fertilizer rates and time of weeding on finger millet tillering

\begin{tabular}{lllll}
\hline \multirow{2}{*}{ Time of weeding $\times$ Fertilizer rates } & \multicolumn{3}{c}{ Number of Tillers } \\
\cline { 2 - 5 } & $20 \& 45$ DAS & 20 DAS & 30 DAS & 45 DAS \\
\hline 2 & 3.50 & 2.72 & 1.58 & 2.13 \\
3 & 2.95 & 2.48 & 2.62 & 2.00 \\
5 & 2.55 & 2.70 & 1.67 & 2.22 \\
6 & 2.08 & 3.03 & 1.6 & 2.2 \\
7 & 3.52 & 3.23 & 2.5 & 2.76 \\
\hline LSD & $1.22^{\text {ns }}$ & $0.88^{*}$ & $1.39^{\text {ns }}$ & $1.05^{\text {ns }}$ \\
CV $(\%)$ & 35.10 & 26.2 & 58.8 & 38.9 \\
\hline
\end{tabular}

Note. $2=\mathrm{N}_{16.6}$ and $\mathrm{P}_{10.6} ; 3=\mathrm{P}_{10.6} ; 5=\mathrm{N}_{16.6} ; 6=\mathrm{N}_{0}, \mathrm{P}_{0} ; 7=\mathrm{N}_{83}$ and $\mathrm{P}_{52} ;$ DAS = Days after Sowing; ns $=$ not significant; * significant at $\mathrm{P}=0.05$.

\subsubsection{Growth Vigor}

The interaction of fertilizer micro-dosing with time of weeding was significant $(\mathrm{P}<0.05)$ when weeding was done at 20 DAS and 30 DAS. Though there was high and positive interaction between fertilizer micro-dosing and weeding time at $30 \mathrm{DAS}$, the highest growth vigor was recorded with a combination of $\mathrm{N}$ and $\mathrm{P}$ micro-dose $\left(\mathrm{N}_{16.6}\right.$ and $\left.\mathrm{P}_{10.6}\right)$ with weeding at 20 DAS (4.00) (Table 2).

Table 4. Interaction effect between fertilizer rates and time of weeding on finger-millet growth vigor

\begin{tabular}{lllll}
\hline \multirow{2}{*}{ Time of weeding $\times$ Fertilizer rates } & \multicolumn{3}{c}{ Growth Vigor Score } \\
\cline { 2 - 5 } & $20 \& 45$ DAS & 20 DAS & 30 DAS & 45 DAS \\
\hline 2 & 3.83 & 4.00 & 3.50 & 3.00 \\
3 & 3.17 & 3.17 & 2.83 & 2.50 \\
5 & 3.33 & 3.33 & 3.00 & 2.50 \\
6 & 3.00 & 3.33 & 2.83 & 2.17 \\
7 & 3.92 & 3.97 & 4.00 & 3.00 \\
\hline LSD & $0.72^{\text {ns }}$ & $0.65^{*}$ & $0.795^{* *}$ & $1.00^{\text {ns }^{*}}$ \\
CV $(\%)$ & 17.6 & 15.4 & 20.7 & 32.1 \\
\hline
\end{tabular}

Note. $2=\mathrm{N}_{16.6}$ and $\mathrm{P}_{10.6} ; 3=\mathrm{P}_{10.6} ; 5=\mathrm{N}_{16.6} ; 6=\mathrm{N}_{0}, \mathrm{P}_{0} ; 7=\mathrm{N}_{83}$ and $\mathrm{P}_{52} ; \mathrm{DAS}=$ Days after Sowing; $\mathrm{ns}=$ not significant; * significant at $\mathrm{P}=0.05 ; * *$ significant at $\mathrm{P}=0.001$.

\subsubsection{Days to $50 \%$ Flowering}

Interaction of fertilizer micro-dosing with time of weeding was significant $(\mathrm{P}<0.05)$ when finger-millet was weeded at 20 and 45 DAS and non-significant when weeded at 20,30, and 45 DAS. However, the lowest days to $50 \%$ flowering was observed at micro-dose $\left(\mathrm{N}_{16.6}\right.$ and $\left.\mathrm{P}_{10.6}\right)$ and weeding at 20 and 45 DAS (Table 5).

Table 5. Effect of fertilizer rates and time of weeding on finger-millet days to $50 \%$ flowering

\begin{tabular}{lllll}
\hline \multirow{2}{*}{ Time of weeding $\times$ Fertilizer rates } & \multicolumn{4}{c}{ Days to 50\% Flowering } \\
\cline { 2 - 5 } & $20 \& 45$ DAS & 20 DAS & 30 DAS & 45 DAS \\
\hline 2 & 52.2 & 53.3 & 54.0 & 54.3 \\
3 & 54.3 & 54.5 & 55.0 & 53.0 \\
5 & 54.6 & 54.8 & 56.7 & 55.7 \\
6 & 55.2 & 54.3 & 55.7 & 55.3 \\
7 & 52.8 & 52.8 & 54.8 & 53.7 \\
\hline LSD & $2.2^{*-1}$ & $3.2^{\text {ns }}$ & $3.2^{\text {ns }}$ & $3.3^{\text {ns }}$ \\
CV $(\%)$ & 3.4 & 4.9 & 4.9 & 5.1 \\
\hline
\end{tabular}

Note. $2=\mathrm{N}_{16.6}$ and $\mathrm{P}_{10.6} ; 3=\mathrm{P}_{10.6} ; 5=\mathrm{N}_{16.6} ; 6=\mathrm{N}_{0}, \mathrm{P}_{0} ; 7=\mathrm{N}_{83}$ and $\mathrm{P}_{52} ;$ DAS = Days after Sowing; ns $=$ not significant; * significant at $\mathrm{P}=0.05$. 


\subsubsection{Plant Height}

The interaction of fertilizer rates (micro-dosing) with time of weeding did not significantly affect $(\mathrm{P}<0.05)$ finger-millet plant height in all the four weeding times, however, weeding alone at different times $(20 \& 45,20$, 30 and 45 DAS) significantly influenced finger-millet height (Figure 1).

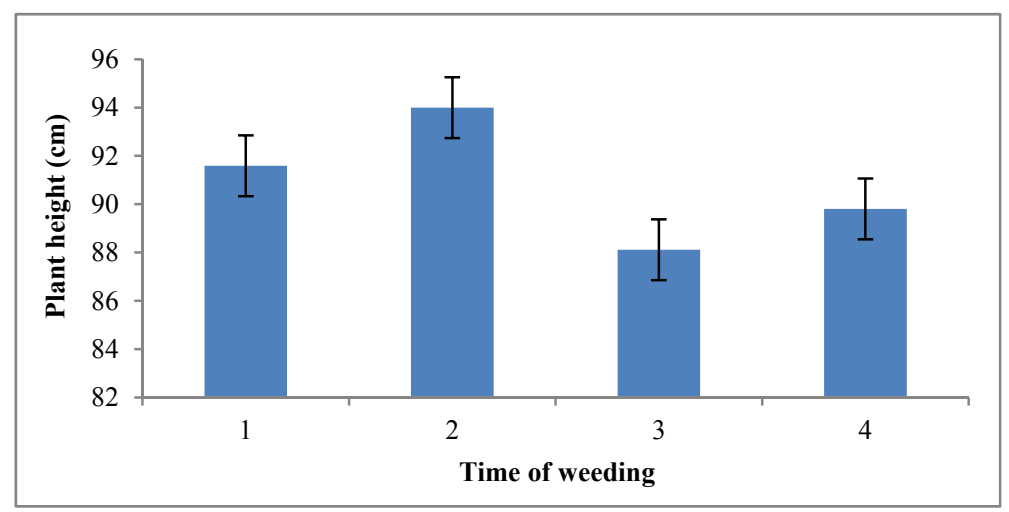

Figure 1. Effect of time of weeding on finger-millet growth height

Note. 1: Weeding twice at 20 and 45 days after sowing; 2: Weeding once at 20 days after sowing; 3: Weeding once at 30 days after sowing; 4 : Weeding once at 45 days after sowing.

\subsubsection{Maturity Time}

The interaction of weeding once $(20$ DAS $) \times$ fertilizer rates (micro-dosing) significantly $(\mathrm{P}<0.05)$ influenced finger-millet maturity time. However, interaction of weeding times $(20$ and 45, 30 and 45$) \times$ fertilizer rates did not significantly influence maturity time.

Table 6. Effect of fertilizer rates and time of weeding on finger-millet maturity time

\begin{tabular}{lllll}
\hline \multirow{2}{*}{ Time of weeding $\times$ Fertilizer rates } & \multicolumn{4}{c}{ Maturity time (days) } \\
\cline { 2 - 5 } & $20 \& 45$ DAS & 20 DAS & 30 DAS & 45 DAS \\
\hline 2 & 90.7 & 93.2 & 94.3 & 95.2 \\
3 & 96.0 & 94.8 & 93.2 & 92.5 \\
5 & 93.7 & 97.3 & 95.2 & 96.7 \\
6 & 92.3 & 97.3 & 95.3 & 96.8 \\
7 & 93.3 & 94.3 & 94.2 & 93.3 \\
\hline LSD & $3.5^{\text {ns }}$ & $1.96^{* *}$ & $3.0^{\text {ns }}$ & $3.0^{\text {ns }}$ \\
SE & 2.9 & 1.64 & 2.5 & 2.5 \\
CV $(\%)$ & 3.1 & 1.7 & 2.7 & 2.6 \\
\hline
\end{tabular}

Note. $2=\mathrm{N}_{6.6}$ and $\mathrm{P}_{10.6} ; 3=\mathrm{P}_{10.6} ; 5=\mathrm{N}_{16.6} ; 6=\mathrm{N}_{0}, \mathrm{P}_{0} ; 7=\mathrm{N}_{83}$ and $\mathrm{P}_{52} ; \mathrm{DAS}=$ Days after Sowing; ns $=$ not significant; $* *=$ significant at 0.01 .

\subsubsection{Grain Yield}

The interaction between fertilizer rates and weeding time on finger-millet grain yield was significantly different $(\mathrm{P}<0.05)$. The results indicate that interaction of weeding at $20 \mathrm{DAS}$ and fertilizer micro-dosing gave the highest grain yield $\left(2292 \mathrm{~kg} \mathrm{ha}^{-1}\right)$ while the lowest finger-millet grain yield $\left(907 \mathrm{~kg} \mathrm{ha}^{-1}\right)$ was observed with no fertilizer and weeding at 45 DAS (Table 7). 
Table 7. Effect of interaction between fertilizer rates and timing of weeding on finger-millet yield

\begin{tabular}{|c|c|c|c|c|}
\hline \multirow{2}{*}{ Time of weeding $\times$ Fertilizer rates } & \multicolumn{4}{|c|}{ Grain yield $\left(\mathrm{kg} \mathrm{ha}^{-1}\right)$} \\
\hline & $20 \& 45$ DAS & 20 DAS & $30 \mathrm{DAS}$ & $45 \mathrm{DAS}$ \\
\hline 2 & 2254.0 & 2292.0 & 2159.0 & 2021.0 \\
\hline 3 & 1404.0 & 1404.0 & 1280.0 & 1384.0 \\
\hline 5 & 1616.0 & 1696.0 & 1632.0 & 1718.0 \\
\hline 6 & 848.0 & 1056.0 & 994.0 & 907.0 \\
\hline 7 & 2012.0 & 2134.0 & 2194.0 & 2268.0 \\
\hline LSD & $464.9^{* * *}$ & $747.3^{\bar{*} *}$ & $874.0^{{ }^{*} \bar{*}}$ & $769.3^{* \bar{x}^{-}}$ \\
\hline SE & 390.9 & 3628.5 & 735.0 & 647.0 \\
\hline CV $(\%)$ & 24.0 & 36.6 & 44.5 & 39.0 \\
\hline
\end{tabular}

Note. $2=\mathrm{N}_{16.6}$ and $\mathrm{P}_{10.6} ; 3=\mathrm{P}_{10.6} ; 5=\mathrm{N}_{16.6} ; 6=\mathrm{N}_{0}, \mathrm{P}_{0} ; 7=\mathrm{N}_{83}$ and $\mathrm{P}_{52} ; \mathrm{DAS}=$ Days after Sowing; $\mathrm{ns}=$ not significant; * significant at $0.05 ; * *=$ significant at 0.01 .

\section{Discussion}

\subsection{Number of Tillers and Growth Vigor}

The interaction between $\mathrm{N}$ and $\mathrm{P}$ rates and timing of weeding was significant at $20 \mathrm{DAS}$ for tiller number and at 20 and 30 DAS for growth vigor. These observations are consistent with weed free conditions that existed at application of $\mathrm{N}$ fertilizer. This could be because weeding of finger-millet was done at the critical weed competition period (20 and 30 DAS) which enhanced $\mathrm{N}$ intake. This is in agreement with (Asargew \& Shibabawu, 2014) who reported that weed competition lies between 20 and 30 DAS with which competition for nutrient between finger-millet and weeds would be high and would greatly affect tillering and growth vigor if not controlled. Observed non-significant interaction between $\mathrm{N}$ and $\mathrm{P}$ fertilizer rates and time of weeding (30 and 45 DAS) on tiller number is associated with delayed weeding which could have promoted competition between weeds and finger-millet for $\mathrm{N}$ and $\mathrm{P}$. Moreover, $\mathrm{N}$ is a major nutrient that is responsible for various metabolic processes that promote tillering through enhanced cell division and elongation (Ali, 2010). These metabolic processes are also responsible for accumulation of dry matter, plant height increase and growth vigor (Opole et al., 2013). When weeding is not done on time, the finger-millet would not benefit from the nitrogen applied due to competition for nutrients with weeds. Similar findings were observed by (Ayub, Nadeem, Tahir, Ibrahim, \& Aslam, 2009), who reported an increase in tiller number when $\mathrm{N}$ is applied in a weed free condition.

On the other hand, tillering and growth vigor have been reported to be influenced by amount of $\mathrm{N}$ and $\mathrm{P}$ fertilizer applied, method of application which in turn influences the nutrient use efficiency of crop. Point application which is a method of applying a micro-dose of fertilizer has been reported to enhance nutrient use efficiency in finger-millet (Gupta, Gaur, \& Kumar, 2014; ICRISAT, 2013). This could explain why there was increase in tiller number and growth vigor when $\mathrm{N}$ and $\mathrm{P}$ fertilizer micro-dose was applied and low tillering recorded with no fertilizer.

The impact of single $\mathrm{P}$ fertilizer application on finger-millet tiller number and growth vigor is limited. However, other researchers have reported an indirect contribution of $\mathrm{P}$ on tillering, growth vigor and grain yield. Singh et al. (2017) reported $23 \%$ grain increase in pearl millet when $30 \mathrm{~kg}$ phosphorus and $20 \mathrm{~kg}$ zinc ha ${ }^{-1}$. In addition, it has also been reported that soils with deficient $\mathrm{P}$ have low response to application of other nutrients especially $\mathrm{N}$ (Opiyo, 2004). Therefore, $\mathrm{P}$ levels in the soil directly influence $\mathrm{N}$ absorption by plants which in turn influences tillering and growth vigor. These findings show that phosphorus may not directly affect yield but influence uptake of other nutrients and metabolic processes in plants.

\subsection{Days to $50 \%$ Flowering}

Interaction between fertilizer micro-dosing rates and weeding time significantly reduced days to $50 \%$ flowering. Days to $50 \%$ flowering were lowest (52.2 days) when finger-millet was micro dosed and weeded at 20 and 45 DAS. When micro dosed and weeded at 20,30 and 45 DAS, days to 50\% flowering of finger-millet was not significantly affected. This observation is associated with less weed biomass in plots weeded at 20 and 45 DAS. This could have resulted from reduced finger-millet and weed competition for $\mathrm{N}$ and $\mathrm{P}$, while high weed biomass was recorded in the plots where weeding was conducted at 20,30 and 45 DAS. This could have caused high competition for $\mathrm{N}$ and $\mathrm{P}$ applied between finger-millet and weeds. Weeds being aggressive feeders could have 
deprived finger-millet of the applied N and P. Similarly, Asargew and Shibabawu (2014), reported delayed growth when weeds were not controlled between 20 and 45 DAS.

Interaction between different fertilizer rates had significant influence on days to $50 \%$ flowering. For example, a combination of $\mathrm{N}$ and $\mathrm{P}$ fertilizer micro-dosing reduced finger-millet days to $50 \%$ flowering. Nitrogen and phosphorus fertilizer micro-dose had lower days to $50 \%$ flowering followed by $\mathrm{N}$ fertilizer micro-dose alone. This is attributed to the on-spot method of fertilizer application at the root zone of the finger-millet crop and in smaller quantities as done with micro-dosing. Whereas, for the case of the full dose (macro) it is applied at the root zone of the crop with some quantities spilling and seeping far away from the crop thus encouraging weed growth and competition for nutrients. This agrees with findings by (Gupta et al., 2014) and (Knight, Everman, Jordan, Heiniger, \& Smyth, 2017), who reported that on-spot application of N and P fertilizers enhances proxy release of nutrients around the root zone of the plant there by aiding effective access uptake and nutrient use efficiency which in turn reduces nutrient losses and access by weeds. Though it is difficult to discern what amounts of nutrients are taken up by weeds, there is a correlation between fertilizer application and increased weed germination and growth, (Asargew \& Shibabawu, 2014; Opole et al., 2013). This is because of the high weed competitive advantage over the crops as a result of their faster adaptation to diverse environments making them aggressive and efficient in nutrient uptake than the crops.

\subsection{Plant Height}

Fertilizer rates interaction with time of weeding had no significant influence on plant height. But in plots where fertilizer was applied and weeding done early (20 DAS), the finger-millet plants were taller than those weeded later. This is attributed to the high weed pressure on $\mathrm{N}$ and $\mathrm{P}$ applied as a result of late weeding ( 30 and 45) DAS. The observed difference in plant height is attributed to the critical weed competition period in finger-millet especially at its early stage of growth. The weed competition period falls between 20 to 30 DAS in which some plots were weeded during the experimentation. Gupta et al. (2014) similarly, observed that at the early 30 days and below from the date of sowing (DOS) the rate at which finger-millet grows is low, giving opportunity for the growth of weeds and suppression of finger-millet height. Weeds are aggressive feeders and therefore drain nutrients from the soil more rapidly than the crop more especially at its early stage of establishment making it lack critical nutrients for stem elongation and tillering there by affecting plant height (Knight, Everman, Jordan, Heiniger, \& Smyth, 2017). Weeding at 20 days after sowing gave the highest plant height, this explains the critical weed competition period in finger-millet and therefore critical weeding time for finger-millet to attain good biomass accumulation and consequently tall plants which are often easy to harvest.

\subsection{Maturity Time}

Interaction of fertilizer rates with time of weeding had a significant effect on maturity time at only 20 DAS of weeding. The observed early maturity of finger-millet when weeded at 20 DAS is attributed to weed free situation created after weeding at early stage or slow rate stage of finger-millet growth. This enables the finger-millet to access nutrients from the soil without competition from the weeds thereby making finger-millet to grow faster. Similar findings were reported by Asargew and Shibabawu (2014) and Gupta et al. (2014) who observed that weeding finger-millet from 45 and above DAS was un productive due to interference of the rooting system by hand hoeing there by affecting nutrient absorption by the crop. On the other hand, there was delayed maturity of finger-millet when weeded at 20 and 45 DAS, weeded once at 30 and 45 DAS. This was attributed to destruction of the root network in the soil during late weeding, thereby hampering effective absorption of nutrients by the crop and, hence delaying the growth of finger-millet. Patil and Reddy (2014) also reported that mechanical weed control causes crop injury especially the roots and the stems causing reduction in growth during the healing period.

\subsection{Finger-Millet Grain Yield}

Nitrogen and phosphorus interaction with time of weeding significantly increased finger-millet grain yield. An interaction of $\mathrm{N}$ and $\mathrm{P}$ micro-dosing with time of weeding of 20 DAS had the highest yield recorded; these findings are associated with enhanced nutrient uptake by finger-millet through reduced weed competition for nutrients at the early stage of crop growth due to early weed control. Similar findings were recorded by Asargew and Shibabawu (2014), who observed that finger-millet grain yield increased when weeding was done between 20 and 30 DAS with fertilizer application. Weeding at 20 DAS had higher finger-millet grain yield than weeding at $20 \& 45$ DAS, 30 DAS and 45 DAS with the latter having a negative effect on the yield response of finger-millet. This is similarly attributed to the effect of mechanical weed control which causes crop injury especially the roots and the stems reducing growth during the healing period (Patil \& Reddy, 2014), and also nutrient depletion by weeds. Yet finger-millet requires adequate nutrients at the early stages of growth and at 
flowering and grain filling stage. Asargew and Shibabawu (2014), reported that if nutrient availability to finger-millet crop is affected at the critical growth stages, its yield performance will be hindered. This is in agreement with the findings by Opole et al. (2013), who reported that nutrients, especially NPK are required at the early flowering and grain filling stages of finger-millet growth. Specifically, $\mathrm{P}$ application is vital in initiation and growth of roots that are responsible for uptake of nutrients and moisture from the soil. Furthermore, $\mathrm{P}$ in the soil inhibits formation of excess roots leading to reduction in loss of carbon from the rooting system and reduction of energy production efficiency thereby increasing grain quantity (Wafula, Nicholas, Henry, \& Siambi, 2016).

\section{Conclusion}

Fertilizer micro-dosing of $\mathrm{N}$ and $\mathrm{P}\left(\mathrm{N}_{16.6} \mathrm{~kg} \mathrm{ha}^{-1}\right.$ and $\left.\mathrm{P}_{10.6} \mathrm{~kg} \mathrm{ha}^{-1}\right)$ increased tillering, crop growth, finger-millet grain yield, reduced days to $50 \%$ flowering and maturity time in finger-millet production compared with the full dose of $\mathrm{N}$ and $\mathrm{P}\left(\mathrm{N}_{83} \mathrm{~kg} \mathrm{ha}^{-1}\right.$ and $\left.\mathrm{P}_{52} \mathrm{~kg} \mathrm{ha}^{-1}\right)$.

Weeding once at 20 DAS increased crop growth vigor, plant height, finger-millet grain yield and reduced finger-millet maturity time.

Interaction between fertilizer micro-dosing and time of weeding (20 DAS), contributed to the highest increase in tillering in finger-millet, crop vigor plant and grain yield. It also significantly reduced finger-millet maturity time.

Fertilizer micro-dosing could be used by farmers to enhance soil fertility in finger-millet production.

Micro-dosing $\left(\mathrm{N}_{16.6} \mathrm{~kg} \mathrm{ha}^{-1}\right.$ and $\left.\mathrm{P}_{10.6} \mathrm{~kg} \mathrm{ha}^{-1}\right)$ and weeding once (20 DAS) can be practiced as a package to enhance soil fertility and control weeds in finger-millet production.

Mini fertilizer packets could be promoted.

\section{Acknowledgements}

Many thanks go to my sponsors, Harnessing Opportunities for Productivity Enhancement of Sorghum and Millets II (HOPE II), the McKnight foundation, and the National Semi Arid Resources Research Institute (NaSARRI) for providing me with funds and enabling environment for my studies.

\section{References}

Ali, E. A. (2010). Grain yield and nitrogen use efficiency of pearl millet as affected by plant density, nitrogen rate and splitting in sandy soil. American-Eurasian Journal of Agricultural and Environmental Science, 7, 327-335.

Asargew, F., \& Shibabawu, A. (2014). Appropriate Time for Weed Management for Finger millet (Eleusin coracana Goartn). Journal of Natural Sciences Research, 4(16).

Ayub, M., Nadeem, M. A., Tahir, M., Ibrahim, M., \& Aslam, M. N. (2009). Effect of nitrogen application and harvesting intervals on forage yield and quality of pearl millet (Pennisetum americanum L.). Pakistan Journal of Life and Social Sciences, 7(2), 185-189.

Chandrasekara, A., \& Shahidi, F. (2010). Content of insoluble bound phenolics in millets and their contribution to antioxidant capacity. Journal of Agricultural and Food Chemistry, 58(11), 6706-6714. https://doi.org/ $10.1021 / \mathrm{jf} 100868 \mathrm{~b}$

Das, R. (2013). Genetic divergence studies in Finger millet (Eleusine coracana (L.) Gaertn.) Germplasm (Thesis, Acharya N. G. Ranga Agricultural University).

Ebanyat, P. (2009). A road to food? Efficacy of nutrient management options targeted to heterogeneous soilscapes in the Teso farming system, Uganda. Makerere University, Uganda.

Goron, T. L., \& Raizada, M. N. (2015). Genetic diversity and genomic resources available for the small millet crops to accelerate a New Green Revolution. Frontiers in Plant Science, 6. https://doi.org/10.3389/ fpls.2015.00157

Gupta, S., Gupta, S. M., Gupta, A. K., Gaur, V. S., \& Kumar, A. (2014). Fluctuation of Dof1/Dof2 expression ratio under the influence of varying nitrogen and light conditions: involvement in differential regulation of nitrogen metabolism in two genotypes of finger millet (Eleusine coracana L.). Gene, 546(2), 327-335. https://doi.org/10.1016/j.gene.2014.05.057

Hatier, J.-H. B., Faville, M. J., Hickey, M. J., Koolaard, J. P., Schmidt, J., Carey, B.-L., \& Jones, C. S. (2014). Plant vigour at establishment and following defoliation are both associated with responses to drought in 
perennial ryegrass (Lolium perenne L.). Journal of Experimental Botany, 65(20), 5823-5834. https://doi.org/10.1093/jxb/eru318

ICRISAT. (2013). Annual Report 2013. Retrieved May 15, 2018, from https://issuu.com/icrisat/docs/annual_ report_2013

Kidoido, M. M., Kasenge, V., Mbowa, S., Tenywa, J. S., \& Nyende, P. (2002). Socioeconomic factors associated with finger millet production in eastern Uganda. African Crop Science Journal, 10(1). https://doi.org/ 10.4314/acsj.v10i1.27561

Knight, A. M., Everman, W. J., Jordan, D. L., Heiniger, R. W., \& Smyth, T. J. (2017). Interactions of Nitrogen Source and Rate and Weed Removal Timing Relative to Nitrogen Content in Corn and Weeds and Corn Grain Yield. International Scholarly Research Notices, 2017, Article ID 8961367. https://doi.org/10.1155/ 2017/8961367

Opiyo, A. M. (2004). Effect of Nitrogen Application on Leaf Yield and Nutritive Quality of Black Nightshade (Solanum Nigrum L.). Retrieved May 30, 2018, from http://journals.sagepub.com/doi/10.5367/0000000042 530178

Opole, R. A., Prasad, P. V. V., \& Staggenborg, S. A. (2013). Effect of seeding and nitrogen fertiliser application rates on field performance of finger millet (pp. 127-135). 11th African Crop Science Proceedings, Sowing Innovations for Sustainable Food and Nutrition Security in Africa, October 14-17, 2013, Entebbe, Uganda.

Owere, L. (2013). Genetic studies on head architecture, adaptation and blast resistance of finger millet in Uganda (Thesis, University of KwaZulu Natal, South Africa). Retrieved from http://researchspace.ukzn. ac.za/handle/10413/10917

Owere, L., Tongoona, P., Derera, J., \& Wanyera, N. (2014). Farmers' Perceptions of Finger Millet Production Constraints, Varietal Preferences and Their Implications to Finger Millet Breeding in Uganda. Journal of Agricultural Science, 6(12). https://doi.org/10.5539/jas.v6n12p126

Patil, B., \& Reddy, V. C. (2014). Weed management practices in irrigated organic finger millet (Eleusine coracana (L.) Gaertn.). Sch J Agric Vet Sci, 1(4A), 211-215.

Singh, L., Sharma, P. K., Jajoria, M., Deewan, P., \& Verma, R. (2017). Effect of Phosphorus and Zinc Application on Growth and Yield Attributes of Pearl millet (Pennisetum glaucum L.) under Rainfed Condition. Journal of Pharmacognosy and Phytochemistry, 6(1), 388-391.

UBOS. (2010). UBOS report 2010, Ugnda census 2010. Kampala, Uganda.

UBOS. (2016). Uganda statistical abstract on agricultural cencus 2016. Kampala, Uganda.

Wafula, W. N., Nicholas, K. K., Henry, O. F., \& Siambi, M. (2016). Finger millet (Eleusine coracana L.) grain yield and yield components as influenced by phosphorus application and variety in Western Kenya. Tropical Plant Research, 3(3), 673-680. https://doi.org/10.22271/tpr.2016.v3.i3.088

Wanyera, N. M. W. (2007). Finger-millet (Eleusine coracana (L.) Gaertn.) in Uganda. In M. A. Mgonja, J. M. Lenne, E. Manyasa, \& S. Sreenivasaprasad (Eds.), Proceedings of the First International Finger Millet Stake-Holders Workshop, Projects R8030 \& 8445, UK Department for International Development-Crop Protection Programme Held on September13-14, 2005. Washington DC, USA.

\section{Copyrights}

Copyright for this article is retained by the author(s), with first publication rights granted to the journal.

This is an open-access article distributed under the terms and conditions of the Creative Commons Attribution license (http://creativecommons.org/licenses/by/4.0/). 